\title{
Asymptomatic arteritis of the uterine cervix
}

\author{
I. D. ANSELL, D. J. EVANS, AND D. G. D. WIGHT
}

From the Department of Histopathology, Royal Postgraduate Medical School, Hammersmith Hospital, London, and the Department of Histology, The John Bonnet Clinical Laboratories, Addenbrooke's Hospital, Cambridge

SYNOPSIS A necrotizing arteritis in the uterine cervix is described as an incidental finding in surgical î material from 10 patients. The histological features are compared with those seen in polyarteritis $\infty$ nodosa. Subintimal hyaline deposition and a relative paucity of neutrophil and eosinophil poly- $\rightarrow$ morphs characterized the lesion but the histological appearance was never sufficiently specific to ${ }_{\circ}^{+}$ exclude confidently the possibility of polyarteritis nodosa. None of the patients had evidence of ${ }_{-}^{\supset}$ multisystem disease either at the time of operation or at subsequent follow-up assessment.

The presence of an acute necrotizing arteritis with fibrinoid necrosis in a surgical or biopsy specimen is usually considered indicative of a diagnosis of polyarteritis nodosa with its attendant poor prognosis (Frohnert and Sheps, 1967). The concept of a focal arteritis localized to one organ and producing no symptoms has been increasingly recognized since its first description in the appendix by Plaut in 1932. Subsequently a similar lesion was described in the gallbladder (Bohrod and Bodon, 1970) and an arteritis localized to the skin is also recognized (Ruiter, 1958) although some cases may only be a variant of polyarteritis nodosa in which skin lesions precede the systemic manifestations by a number of years. Isolated asymptomatic necrotizing arteritis has not been recorded in the uterine cervix although Plaut records occasionally instances elsewhere in the female genital tract in his later publication (Plaut, 1951).

\section{Materials and Methods}

A search of the records of the Hammersmith and Addenbrooke's hospitals revealed 10 cases in which an acute necrotizing arteritis was present within the uterine cervix. In the majority of cases only paraffin blocks of tissue were available for study but in five cases the entire uterus had been preserved and the whole cervix could be examined histologically. Arteritis was considered to be present when fibrinoid material and inflammatory cells were present in either a portion or the full circumference of the

Received for publication 20 May 1974. wall of an artery. Sections were stained by haematoxylin and eosin, Martius Scarlet Blue, and $\varphi$ Weigert's elastic technique.

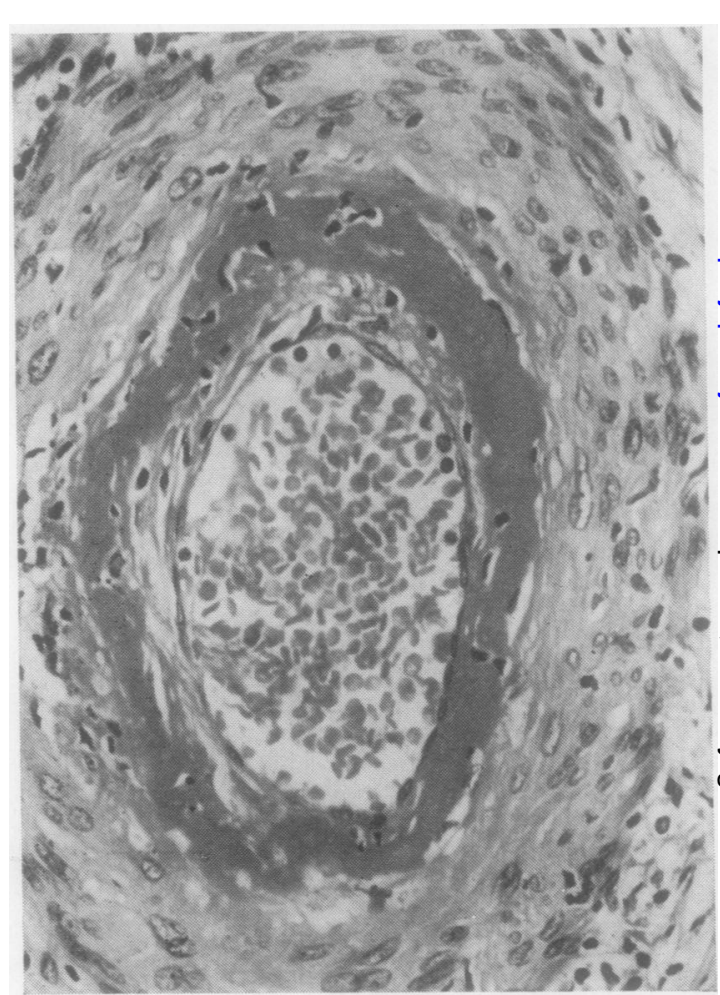

Fig 1 Subintimal hyaline deposition with only scanty inflammatory cell infiltrate $(H$ and $E, \times 411)$ 


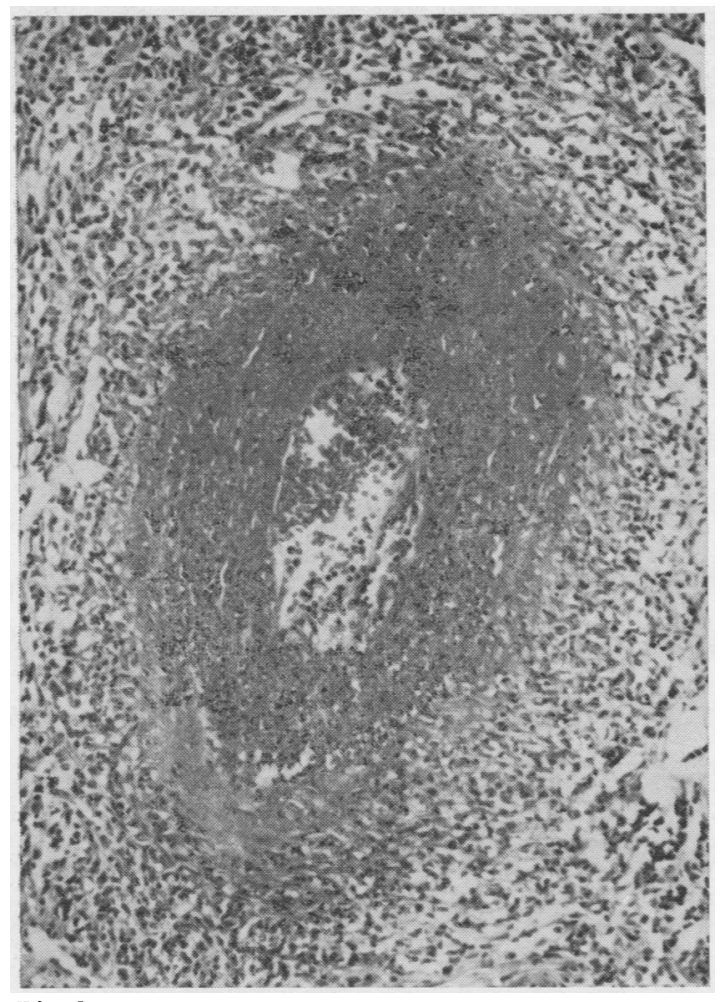

Fig 2

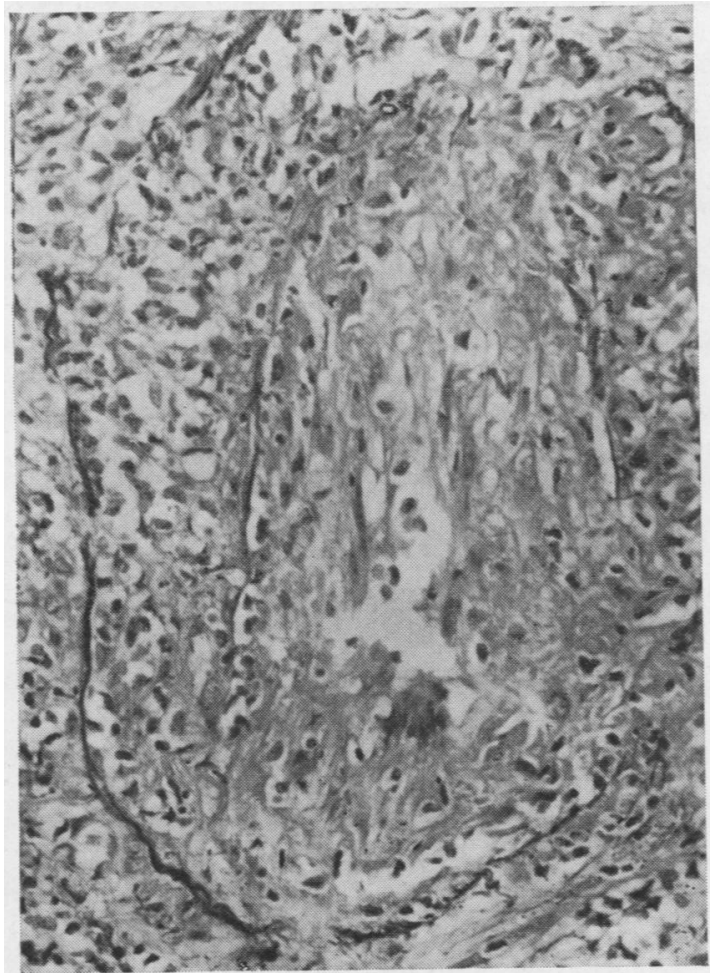

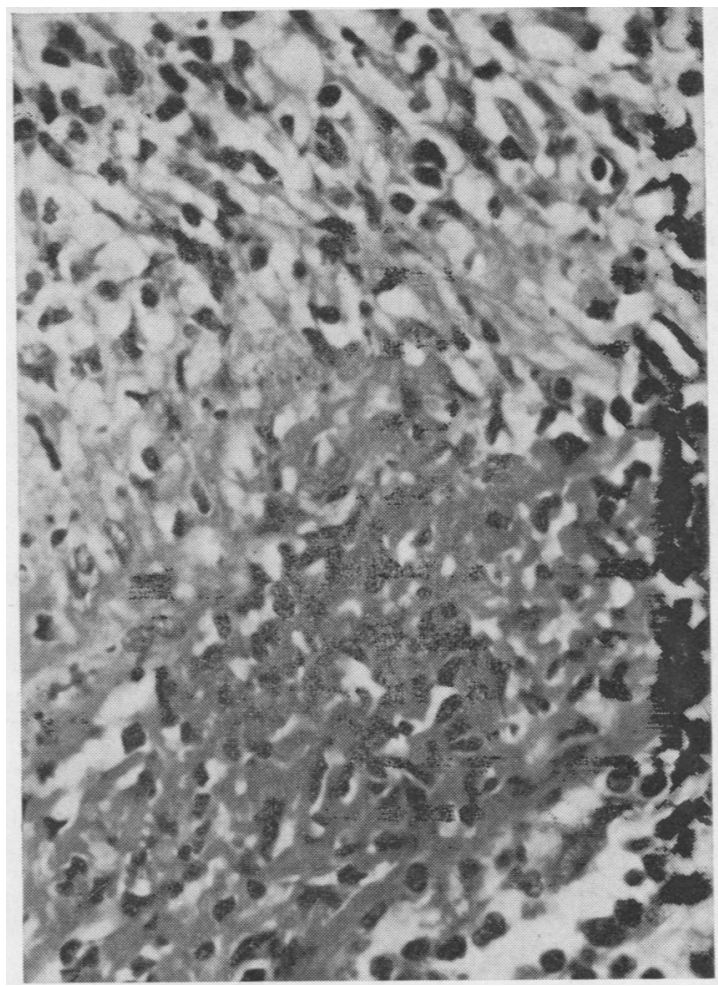

Fig 3

Fig 2 Frank necrotic artery, with fibrinoid and inflammatory cell infiltrate $(H$ and $E, \times 165)$

Fig 3 High-power view of fig 2, showing characteristic mononuclear cell infiltrate with lack of polymorphs ( $H$ and $E, \times 750)$

Fig 4 Disruption of elastic laminae accompanying arteritic lesion (Weigert's elastic stain, $\times$ 411) 


\begin{tabular}{|c|c|c|c|c|c|c|c|c|c|c|c|}
\hline $\begin{array}{l}\text { Case } \\
\text { No. }\end{array}$ & $\begin{array}{l}\text { Age at } \\
\text { Operation }\end{array}$ & Race & Parity & $\begin{array}{l}\text { Years since } \\
\text { last } \\
\text { Pregnant }\end{array}$ & $\begin{array}{l}\text { Presenting } \\
\text { Complaint }\end{array}$ & Operation & Previous Operation & $\begin{array}{l}B P \\
(m m H g)\end{array}$ & ESR & $\begin{array}{l}\text { Follow } \\
\text { Up }\end{array}$ & Vessels Affected \\
\hline 1 & 52 & White & $7+0$ & 10 & $\begin{array}{l}\text { Stress } \\
\text { incontinence }\end{array}$ & Amputation of cervix & & $210 / 110$ & 15 & $15 \mathrm{yr}$ & 1 \\
\hline 2 & 51 & Indian & $4 \div 1$ & 12 & Menorrhagia & Vaginal hysterectomy & $\begin{array}{l}\text { Cervical polypec- } \\
\text { tomy some years } \\
\text { earlier }\end{array}$ & $170 / 95$ & - & $1 / 12$ & 1 \\
\hline 3 & 50 & White & $2+1$ & 19 & Menorrhagia & $\begin{array}{l}\text { Abdominal hysterec- } \\
\text { tomy and bilateral sal- } \\
\text { pingo-oophorectomy }\end{array}$ & & $150 / 90$ & 一 & $2 \frac{1}{2} \mathrm{yr}$ & 1 \\
\hline 4 & 37 & Negro & $1 \div 0$ & 20 & Menorrhagia & $\begin{array}{l}\text { Abdominal hysterec- } \\
\text { tomy and bilateral sal- } \\
\text { pingo-oophorectomy }\end{array}$ & $\begin{array}{l}\text { D \& C } 9 \text { years } \\
\text { earlier. Tuboplasty } \\
6 \text { years earlier }\end{array}$ & $140 / 90$ & 10 & $6 / 12$ & $\begin{array}{l}\text { Approximately } \\
1 / 3 \text { all } \\
\text { arteries }\end{array}$ \\
\hline 5 & 52 & White & $0-0$ & - & Prolapse & Vaginal hysterectomy & $\begin{array}{l}\text { D \& C just before } \\
\text { hysterectomy }\end{array}$ & $150 / 90$ & 5 & $6 \mathrm{yr}$ & $\begin{array}{l}\text { Approximately } \\
1 / 2 \text { large } \\
\text { arteries }\end{array}$ \\
\hline 6 & 45 & White & $3 \div 0$ & 20 & $\begin{array}{l}\text { Positive } \\
\text { cervical } \\
\text { cytology }\end{array}$ & $\begin{array}{l}\text { Abdominal hysterec- } \\
\text { tomy }\end{array}$ & & $140 / 80$ & - & $1 \mathrm{yr}$ & 1 \\
\hline 7 & 41 & White & $5 \div 0$ & 6 & $\begin{array}{l}\text { Menorrhagia } \\
\text { prolapse }\end{array}$ & Vaginal hysterectomy & & $120 / 70$ & - & $2 \mathrm{yr}$ & 1 \\
\hline 8 & 36 & White & $2+0$ & 10 & $\begin{array}{l}\text { Poly- } \\
\text { menorrhoea }\end{array}$ & $\begin{array}{l}\text { Abdominal hysterec- } \\
\text { tomy }\end{array}$ & $\begin{array}{l}\text { EUA, and D \& C } \\
10 \text { days before } \\
\text { operation }\end{array}$ & $110 / 60$ & 5 & $2 / 12$ & 1 \\
\hline 9 & 37 & White & $4 \div 0$ & 5 & $\begin{array}{l}\text { Menorrhagia } \\
\text { prolapse }\end{array}$ & Vaginal hysterectomy & $\begin{array}{l}\text { D \& C } \times 24 \text { years } \\
\text { earlier }\end{array}$ & $110 / 70$ & - & - & $\begin{array}{l}\text { Several large } \\
\text { arteries }\end{array}$ \\
\hline 10 & 34 & White & $5+0$ & 6 & Menorrhagia & Vaginal hysterectomy & $\begin{array}{l}\text { D \& C } 1 \text { year } \\
\text { earlier }\end{array}$ & $110 / 90$ & 15 & $3 / 12$ & 1 \\
\hline
\end{tabular}

Table Clinical and pathological details of patients with arteritis of the vessels of uterine cervix

\section{Results}

\section{PATHOLOGY}

In eight patients a total hysterectomy had been performed and in five this had been done vaginally. One patient had had an amputation of cervix for prolapse and one a cone biopsy following positive cervical cytology. No significant abnormalities were noted macroscopically in any of the specimens.

The arteries affected were usually medium-sized muscular arteries. In seven cases only one affected artery was found despite examination of multiple blocks of the cervix in the three cases in which this was possible. In the other three patients between one quarter and one half of the arteries of the cervix were affected but only in case 4 were abnormal arterioles seen. Fibrinoid material was most commonly found in a distinctive subintimal position (fig 1) and in only three cases was the smudgy appearance characteristic of fibrinoid necrosis seen (fig 2). The cellular infiltrate was predominantly mononuclear in type (fig 3) and neutrophil polymorphs were never a prominent feature although moderate numbers of eosinophils were present in cases 5 and 9. In all cases many karyorrhectic nuclei were observed but in view of the paucity of polymorphs in the area they were not thought to be of polymorph origin. Disruption of the internal elastic lamina was demonstrated in sections stained for elastic tissue in seven cases (fig 4). Although many cases contained a little intraluminal fibrin frank thrombosis was not observed in any of the 10 cases and no aneurysms or areas of infarction were seen.

\section{CLINICAL FEATURES}

The clinical details of the 10 patients are enumerated in the table. The ESR had been measured in five cases and in none was it significantly raised. In only one patient (case 1) was systemic disease present at the time of diagnosis of the cervical arteritis. This female of 52 years was found to have hypertension 8 which responded to medical treatment for many years. She died 15 years after the diagnosis of 0 arteritis; necropsy was unfortunately refused, but she had been in hospital a year before her death and had no evidence of polyarteritis nodosa at that time. Follow up of the other nine patients has been for up $ᄋ$ to six years; all have remained well. Only two 0 patients had any history of exposure to drugs; case 4 N had been on oral contraceptives for three months until three months before her operation and case 9 had chlorpromazine for anxiety before her hysterectomy.

\section{Discussion}

Polyarteritis nodosa was first described in 1866 by Kussmahl and Maier. Their description and that of other early reports was of a condition affecting large muscular arteries, usually near their bifurcation, 
leading to aneurysm formation, thrombosis, and infarction. It was not until 1903 (Veszprémi and Janscó) that the condition was diagnosed on microscopical evidence only. Following this the term came to be used to describe a number of conditions in which inflammatory lesions of arterioles and veins were present in addition to lesions in muscular arteries. Zeek produced a classification of the arteritides in 1952 and although not all authors find this of value (O'Duffy, Scherbel, Reidbard, and McCormack, 1965), no more satisfactory system has emerged since that time. The female genital organs frequently contain foci of arteritis in those patients who come to necropsy. Patalano and Sommers (1961) noted uterine lesions in six of 17 necropsied cases of polyarteritis nodosa but no report has yet been published describing specifically arteritic lesions confined to the female genital tract. The possibility that acute necrotizing arteritis might be asymptomatic and localized to one organ was first proposed by Plaut in 1932 . He later published a series of 88 cases in which an acute arteritis was discovered as an incidental finding in surgically removed appendices (Plaut, 1951). It was perhaps misleading to call his cases asymptomatic as many would have had abdominal symptoms which led to laparotomy and removal of the appendix. Some justification for the use of this term is found on considering the incidence of arteritis in those with a microscopical diagnosis of acute appendicitis, nine of 2282 and those without this diagnosis, 79 of 4292. Plaut also found four cases of acute arteritis of the appendix amongst 107 necropsies in which this organ had been examined. Similar difficulties arise when considering arteritic lesions in cholecystectomy specimens, for whilst the gallbladder was macroscopically normal in the first report of polyarteritis nodosa affecting the gallbladder (Massachusetts General Hospital, 1947) the patient had multisystem disease at the time of publication. However, Bohrod and Bodon (1970) have recently described four patients with acute arteritis in cholecystectomy specimens who have remained well on follow up.

The skin is affected in approximately one quarter of cases of polyarteritis and on occasion may be the only organ affected both at the time of presentation and on subsequent follow up (Lyell and Church, 1954). Ruiter (1958) subdivided the arteritides localized to the skin into those affecting arteries of the dermis and those affecting the muscular arteries at the border of the dermis and subcutaneous tissue.

None of our patients has developed signs or symptoms of polyarteritis nodosa and the condition may thus be labelled asymptomatic arteritis. The microscopic picture of prominent subintimal hyaline deposition, paucity of eosinophil and neutrophil polymorphs, and lack of thrombosis, aneurysm formation, or infarction differs considerably from the classical picture seen in polyarteritis nodosa (Arkin, 1930). It is of considerable interest that the histological picture in our cases is almost identical with that described in the appendix by Plaut although Bohrod and Bodon's cases of asymptomatic arteritis of the gallbladder had aneurysms and a considerable eosinophil infiltrate. A knowledge of those organs of the body in which asymptomatic arteritis may occur is of importance both to prevent unnecessary therapy and to avoid misdiagnosis in the future (Massachusetts General Hospital, 1973).

The aetiology of polyarteritis nodosa is still problematical. It is usually considered to be due to hypersensitivity, this thesis being supported by its association with asthma, eosinophilia, and drug hypersensitivity and the similarity to the arteritic lesions seen in serum sickness. More recently immunoglobulin and complement have been demonstrated in the lesions of polyarteritis nodosa, and Gocke, Hsu, Morgan, Bombardieri, Lockshin, and Christian (1970) have demonstrated that there is a significant association between polyarteritis nodosa and Australia antigenaemia and in one case found hepatitis-associated antigen (HAA) in the arterial lesion as well as immunoglobulin $M$ and the third component of complement. They pointed out that only a minority of cases of arteritis had HAA. Nevertheless the implication that similar types of mechanism could be involved in other cases is inescapable. In a proportion of cases of cutaneous vasculitis identification of a bacterial antigen that could be responsible for the lesion has been achieved (Parish, 1971) and the question now arises as to why immunological damage should affect specific groups of vessels to the exclusion of others.

It has been proposed that the damaging effect of vasoactive amines on endothelial cells may predispose to localization of complexes at that site (Kniker, 1972). Although it might be possible to explain localization in sites such as skin and cervix by differential trauma to vessels it is difficult to see how this argument could be applied to the appendix and gallbladder.

No evidence of immune or drug hypersensitivity could be elicited in our cases. Affected arteries all lay deep to the cervical epithelium so that trauma or proximity to superficial inflammatory foci could similarly be excluded. No relationship with parity was readily apparent. The pathogenesis of these cases must remain speculative as is their relationship to systemic polyarteritis.

We thank Professor J. C. M. Browne, $\mathrm{Mr} \mathbf{H}$. Gordon, and Mr R. E. Robinson and the other 
gynaecologists and physicians who cared for these patients, for allowing us access to clinical details.

\section{References}

Arkin, A. (1930). A clinical and pathological study of periarteritis nodosa. Amer. J. Path., 6, 401-426.

Bohrod, M. G., and Bodon, G. F. (1970). Isolated polyarteritis nodosa of the gall bladder. Amer. Surg., 36, 681-685.

Frohnert, P. P., and Sheps, S. G. (1967). Long-term follow-up study of periarteritis nodosa. Amer. J. Med., 43, 8-14.

Gocke, D. J., Hsu, K., Morgan, C., Bombardieri, S., Lockshin, M., and Christian, C. L. (1970). Association between polyarteritis and Australia antigen. Lancet, 2, 1149-1153.

Kniker, W. T. (1972). Modulation of the inflammatory response in vivo; prevention or amelioration of immune complex disease. In Inflammation; Mechanisms and Control, edited by I. H. Lepow and P. A. Ward, pp. 335-367. Academic Press, New York and London.

Kussmaul, A., and Maier, R. (1866). Ueber eine bisher nicht beschriebene eigenthümliche Arterienerkrankung (Periarteritis nodosa), die mit Morbus Brightii und rapid fortschreitender allgemeiner Muskellahmung einhergeht. Dtsch. Arch. klin. Med., 1, 484-518.

Lyell, A., and Church, R. (1954). The cutaneous manifestations of polyarteritis nodosa. Brit. J. Derm., 66, 335-343.

Massachusett's General Hospital (1947). Case Records, no. 33241. New. Engl. J. Med., 236, 909-915.

Massachusetts General Hospital (1973). Case Records, no. 51-1973. $\frac{\omega}{\widehat{D}}$ New. Engl. J. Med., 289, 1360-1366.

O'Duffy, J. D., Scherbel, A. L., Reidbord, H. E., and McCormack, L. J. (1965). Necrotizing angiitis. 1. A clinical review of twenty- ڤ) seven autopsied cases. Cleveland clin. Quart., 32, 87-98.

Parish, W. E. (1971). Studies on vasculitis. 1. Immunoglobulins, $\beta 1 c, \overrightarrow{0}$ $\mathrm{C}$-reactive protein, and bacterial antigens in cutaneous vasculitis lesions. Clin. Allergy., 1, 97-109.

Patalano, V. J., and Sommers, S. C. (1961). Biopsy diagnosis of polyarteritis nodosa. Arch. Path., 72, 1-7.

Plaut, A. (1932). Focal arteriolitis. Amer. J. Path., 8, 620-621

Plaut, A. (1951). Asymptomatic focal arteritis of the appendix. Amer. J. Path., 27, 247-264.

Ruiter, M. (1958). The so-called cutaneous type of periarteritis $\infty$ nodosa. Brit. J. Derm., 70, 102-106.

Veszprémi, D., and Janscó, M. (1903). Ueber einen fall von periarteritis nodosa. Beitr. path. Anat., 34, 1-25.

Zeek, P. M. (1952). Periarteritis nodosa: a critical review. Amer. J. 윽 clin. Path., 22, 777-790.

\section{The July 1974 Issue}

\section{THE JULY 1974 ISSUE CONTAINS THE FOLLOWING PAPERS}

The structure and growth of valve-pocket thrombi in femoral veins SIMON SEVITT

Pathological features of hypertrophic obstructive cardiomyopathy M. J. DAVIES, ARIELA POMERANCE, AND R. D. TEARE

Indolent mucoid carcinoma of stomach W. L. BRANDER, P. R. G. NEEDHAM, AND A. D. MORGAN

A membrane filter method for correlating colposcopic, histological, and cytological pictures: The application to nuclear DNA measurements G. P. BURN, A. SINGER, AND A. I. SPRIGGS

Intracellular immunoglobulins J. BURNS, MARIA HAMBRIDGE, AND C. R. TAYLOR

Thiamine deficiency and oxalosis WILliam $\mathbf{R}$. SALYER AND DIANE C. SALYER

Osmotically stable $\mathrm{L}$ forms of Haemophilus influenzae and their significance in testing sensitivity to penicillins DAVID E. ROBERTS, A. INGOLD, SUSAN V. WANT, AND THE LATE J. ROBERT MAY

Thymidine-dependent Escherichia coli infection and some associated laboratory problems ELIZABETH I. TANNER AND C. H. BULLIN

Evaluation of commercially available antisera for serotyping of Pseudomonas aeruginosa A. H. ALDUJAILI AND D. M. HARRIS
Resistotyping of Proteus mirabilis and a comparison with other methods of typing I. M. KASHBUR, R. H. GEORGE, AND G. A. J. AYLIFFE

The isolation of anaerobic bacteria from wound sWabs SUSAN PEACH AND L. HAYEK

The influence of paraproteinaemia on the Technicon automated platelet counter P. C. HALL AND R. M. IBBOTSON

A test system for the biological safety cabinet S. W. B. NEWSOM

The use of SI units in reporting results obtained in $\frac{\mathrm{O}}{7}$ hospital laboratories D. N. BARON, P. M. G. $\frac{7}{0}$ BROUGHTON, M. COHEN, T. S. LANSLEY, S. M. LEWIS, AND N. K. SHINTON

\section{Technical method}

Latex spheres: A new use in transmission electron microscopy M. E. TITFORD

Letters to the Editor

Notices

Book reviews

Copies are still available and may be obtained from the PUBLISHING MANAGER, BRITISH MEDICAL ASSOCIATION, TAVISTOCK SQUARE, WC1H 9JR, price $£ 1.05$ 